\title{
Changes in N, K, and Fatty Acid Composition of Black Cumin Seeds Affected by Nitrogen Doses under Supplemental Potassium Application
}

\author{
Zehra Aytac, ${ }^{1}$ Nurdilek Gulmezoglu, ${ }^{2}$ Tugce Saglam, ${ }^{3}$ Engin Gokhan Kulan, ${ }^{1}$ \\ Ugur Selengil, ${ }^{4}$ and Halit Levent Hosgun ${ }^{5}$ \\ ${ }^{1}$ Department of Field Crops, Faculty of Agriculture, Eskisehir Osmangazi University, Eskisehir, Turkey \\ ${ }^{2}$ Department of Soil Science and Plant Nutrition, Faculty of Agriculture, Eskisehir Osmangazi University, Eskisehir, Turkey \\ ${ }^{3}$ The Ministry of Food, Agriculture and Livestock, Directorate of Cifteler, Eskisehir, Turkey \\ ${ }^{4}$ Department of Chemical Engineering, Faculty of Engineering and Architecture, Eskisehir Osmangazi University, \\ Meselik Campus, Eskisehir, Turkey \\ ${ }^{5}$ Department of Chemical Engineering, Faculty of Natural Sciences, Architecture and Engineering, Bursa Technical University, \\ Bursa, Turkey \\ Correspondence should be addressed to Engin Gokhan Kulan; egk_88@hotmail.com
}

Received 27 January 2017; Revised 14 April 2017; Accepted 23 April 2017; Published 4 June 2017

Academic Editor: Mostafa Khajeh

Copyright (C) 2017 Zehra Aytac et al. This is an open access article distributed under the Creative Commons Attribution License, which permits unrestricted use, distribution, and reproduction in any medium, provided the original work is properly cited.

This study was carried out to determine the efficiency of nitrogen $(\mathrm{N})$ doses $\left(0,30,60\right.$, and $\left.90 \mathrm{~kg} \mathrm{Nha}^{-1}\right)$ under supplemental potassium $(\mathrm{K})$ application $\left(50 \mathrm{~kg} \mathrm{~K}_{2} \mathrm{O} \mathrm{ha}^{-1}\right.$ ) on black cumin in 2011 and 2012 . The results showed that increased $\mathrm{N}$ levels resulted in increasing seed yield and $\mathrm{N}$ and $\mathrm{K}$ contents in seed, while oil content decreased. The seed yield and oil yield were peaked at the doses of $60 \mathrm{~kg} \mathrm{Nha}^{-1}$ and $50 \mathrm{~kg} \mathrm{Kha}^{-1}$. An increase in $\mathrm{N}$ doses caused a reduction in oil content regardless of $\mathrm{K}$ supply. Saturated fatty acids and oleic acid were slightly increased by $\mathrm{K}$ application, while minor changes in linoleic acid were detected. It was concluded that $60 \mathrm{~kg} \mathrm{~N} \mathrm{ha}^{-1}$ with supplemental $\mathrm{K}$ application should be advised for enhancement in seed yield, oil yield, and $\mathrm{N}$ and $\mathrm{K}$ contents in seeds of black cumin without significant changes in fatty acid composition.

\section{Introduction}

Black cumin (Nigella sativa L.), an annual herbaceous plant, has been used for centuries for spice, medicinal, and culinary purposes. It is extensively cultivated from Morocco to northern India and Bangladesh and in East Africa and Russia for spice, while it is grown on a minor scale mainly for medicinal purposes in North America, Europe, and Southeast Asia [1]. Its seeds have been utilized as a food preservative to flavor sauces, pickles, and meat dishes and are sprinkled on bread and cheese [2]. The seeds and extracts have antioxidant [3], antidiabetic [4], antihistaminic [5], antihypertensive [6], antiinflammatory, analgesic [7], antimicrobial [8], and antitumor [9] effects. In addition, the oil extracted from seeds of black cumin is rich in linoleic, oleic, and palmitic acids [10-12].
Black cumin is generally adapted to disturbed soils and semiarid regions [13]. In these areas, low soil fertility due to insufficient organic matter is the main obstacle limiting high yielding productivity, and consequently $\mathrm{N}$ fertilization must be applied for improvement in biomass and seed yield. Nitrogen is one of the essential nutrients affecting the plant growth and development, being an essential component of the proteins which builds cell materials and plant tissue [14]. Several findings have shown the positive effects of $\mathrm{N}$ fertilization on the seed yield and seed oil quality of black cumin by Ashraf et al. [15], Özgüven and Sekeroğlu [16], and Shah [17].

Potassium, which is known to affect several physiological activities in the plant, withstands water stress, increases resistance to diseases, and enhances protein synthesis and 
TABLE 1: Monthly climatic data of the experimental field and long-term average during growing seasons.

\begin{tabular}{|c|c|c|c|c|c|c|}
\hline \multirow{2}{*}{ Month } & \multicolumn{3}{|c|}{ Mean temperature $\left({ }^{\circ} \mathrm{C}\right)$} & \multicolumn{3}{|c|}{ Total precipitation $(\mathrm{mm})$} \\
\hline & 2011 & 2012 & Long-term & 2011 & 2012 & Long-term \\
\hline March & 4.8 & 1.5 & 4.9 & 16.6 & 56.4 & 29.6 \\
\hline April & 8.0 & 11.9 & 9.7 & 60.8 & 22.1 & 44.3 \\
\hline May & 13.7 & 14.4 & 14.9 & 92.3 & 80.9 & 39.4 \\
\hline June & 18.1 & 20.1 & 19.2 & 32.0 & 0.0 & 24.4 \\
\hline July & 23.4 & 22.8 & 22.0 & 20.0 & 5.5 & 13.4 \\
\hline August & 20.6 & 20.8 & 22.0 & 2.2 & 3.5 & 9.0 \\
\hline Mean/total & 14.8 & 15.3 & 15.5 & 223.9 & 168.4 & 160.1 \\
\hline
\end{tabular}

quality. However, deficient $\mathrm{K}$ concentration in plant inhibited $\mathrm{N}$ uptake and photosynthetic carbon assimilation [18]. Nitrogen and $\mathrm{K}$ are required by crops especially during the beginning of growth to maintain development and expansion of the leaf canopy [19]. The optimum yield and crop quality can be obtained at optimal $\mathrm{N}$ and $\mathrm{K}$ rates. Insufficient $\mathrm{K}$ may lead to reduced $\mathrm{N}$ uptake, less developed roots, susceptibility to water loss, wilting, and lodging [20]. Moderate $\mathrm{N}$ fertilization results in higher yield increases in many crops after $\mathrm{K}$ application compared to $\mathrm{N}$ and $\mathrm{K}$ applied separately [21]. The increase in $\mathrm{N}$ uptake through $\mathrm{K}$ application ensures increased $\mathrm{N}$ use efficiency [22]. The efficiency of $\mathrm{N}$ and $\mathrm{K}$ fertilizer application is affected by numerous factors, including soil type, the soil's original $\mathrm{N}$ and $\mathrm{K}$ supplying capacity, crop cultivars, organic matter, and the levels of other nutrients $[23,24]$. The interactions between $\mathrm{N}$ and $\mathrm{K}$ on crop growth and final yield which occur at the agronomic level are due to their underlying physiological interactions on tissue hydration and osmotic adjustment. On the other hand, the optimum level of $\mathrm{N}$ and $\mathrm{K}$ to be applied should be determined due to unnecessary expenses and environmental pollution like nitrate leaching, water contamination, and eutrophication in case of excessive $\mathrm{N}$ uses $[25,26]$. Contrarily, $\mathrm{K}$ does not cause a significant environmental pollution by leaching or contamination, while K leaching, which affects adversely plant growth and quality, may usually occur in sandy soils and high rainfall areas [27, 28].

This study was aimed at determining the effects of increasing $\mathrm{N}$ doses on seed yield, oil content, and fatty acid composition of black cumin with or without supplemental $\mathrm{K}$ fertilization.

\section{Materials and Methods}

This research was carried out during the two years of 2011 and 2012 at the Faculty of Agriculture, Eskisehir Osmangazi University, located at an altitude of $789 \mathrm{~m}$ and between $39^{\circ} 48^{\prime} \mathrm{N}$ and $30^{\circ} 31^{\prime} \mathrm{E}$. A local population (Dereyalak village, İnönü, Eskisehir) of black cumin was used as seed material. The soil of the experimental area was alkaline (soil/water-1/2.5 $\mathrm{pH}$ : 8.09 ) loam textured and calcareous with a low content $(0.91 \%)$ of organic matter. Phosphorus content $\left(6.4 \mathrm{mg} \mathrm{kg}^{-1}\right)$ of the soil was insufficient but the $\mathrm{K}$ content $\left(160 \mathrm{mg} \mathrm{K} \mathrm{kg}^{-1}\right)$ of the soil was sufficient.
As shown in Table 1, the total precipitation in 2011 (223.9 mm) was higher than that in 2012 (168.4 mm); however, the average temperature was lower in the first year $\left(14.8^{\circ} \mathrm{C}\right)$ than in the second year $\left(15.3^{\circ} \mathrm{C}\right)$. The long-term average temperature $\left(15.5^{\circ} \mathrm{C}\right)$ and the total precipitation $(160.1 \mathrm{~mm})$ were approximately equal to those of the second year.

The experiment was arranged in a split plot design with three replications ( $\mathrm{K}$ to main plots and $\mathrm{N}$ doses to subplots), and the plot size was $5.0 \mathrm{~m} \times 1.8 \mathrm{~m}$, consisting of 6 rows. Seeds were sown at the rate of $15 \mathrm{~kg} \mathrm{ha}^{-1}$ at the end of March in both years using rows with $30 \mathrm{~cm}$ spacing on a well-prepared seedbed. Nitrogen fertilization was applied as ammonium nitrate $(33 \% \mathrm{~N})$ at four doses (control, 30, 60, and $90 \mathrm{~kg} \mathrm{Nha}^{-1}$ ), and all of the plots received half of $\mathrm{N}$ before sowing with the remaining being applied at flowering stage. Phosphorus fertilization was applied at sowing $\left(40 \mathrm{~kg} \mathrm{ha}^{-1}\right)$ in the form of triple superphosphate (TSP $42 \% \mathrm{P}_{2} \mathrm{O}_{5}$ ). The plots fertilized with $\mathrm{K}$ were not fertilized with TSP because the $\mathrm{K}$ fertilization was applied in the form of monopotassium phosphate (0-52-34) at a dose of $50 \mathrm{~kg} \mathrm{~K}_{2} \mathrm{O} \mathrm{ha}^{-1}$. Potassium and $\mathrm{N}$ fertilizers were not applied to the control plots. The weeds were controlled manually by hoeing. The plants were not irrigated in the first year because of sufficient precipitation, while the plants were irrigated twice in the second year after sowing for seedling emergence and during the flowering period. Harvest and handling were performed manually at the beginning of August.

The seeds after harvesting and cleaning were finely ground using an electrical grinder (Bosch, Germany) for oil content. The samples were dried at $105^{\circ} \mathrm{C}$ for 3 hours in a drying oven (Binder ED 115, Germany). The grounded $10 \mathrm{~g}$ sample was fed into a Soxhlet apparatus fitted with a $500 \mathrm{~mL}$ round-bottom flask and a condenser. The extraction was performed on a water bath at $40-60^{\circ} \mathrm{C}$ for $4 \mathrm{~h}$ with $200 \mathrm{~mL}$ petroleum ether. The solvent was distilled off under vacuum in a rotary evaporator. The seed oil was weighed and transferred into glass sealed amber dark bottles. The solvent residue in the seed oil was removed and stored at $-18^{\circ} \mathrm{C}$ until analysis. The percentage of seed oil content was calculated by gravimetric methodology on the basis of dry matter [29]. The oil yield was calculated by seed oil content $(\%) \times$ seed yield $\left(\mathrm{kg} \mathrm{ha}^{-1}\right)$.

The fatty acid composition of the oil samples extracted was analyzed after derivatization to fatty acid methyl esters 
TABLE 2: Main effects of $\mathrm{N}$ doses and supplemental K on seed yield, seed oil content, oil yield, and $\mathrm{N}$ and $\mathrm{K}$ contents in seeds of black cumin.

\begin{tabular}{|c|c|c|c|c|c|}
\hline Year & Seed yield $\left(\mathrm{kg} \mathrm{ha}^{-1}\right)$ & Seed oil content (\%) & Oil yield $\left(\mathrm{kg} \mathrm{ha}^{-1}\right)$ & $\mathrm{N}$ content $(\%)$ & K content (\%) \\
\hline 2011 & $1080^{\mathrm{a}}$ & $43.2^{\mathrm{a}}$ & $466^{\mathrm{a}}$ & 3.18 & $1.68^{\mathrm{a} \dagger}$ \\
\hline 2012 & $886^{\mathrm{b}}$ & $32.6^{\mathrm{b}}$ & $288^{\mathrm{b}}$ & 3.11 & $1.61^{\mathrm{b}}$ \\
\hline \multicolumn{6}{|c|}{ Potassium $\left(\mathrm{kg} \mathrm{K}_{2} \mathrm{O} \mathrm{ha}^{-1}\right)$} \\
\hline Control & $950^{\mathrm{b}}$ & $37.3^{\mathrm{b}}$ & $359^{\mathrm{b}}$ & $2.99^{\mathrm{b}}$ & $1.57^{\mathrm{b}}$ \\
\hline 50 & $1015^{\mathrm{a}}$ & $38.5^{\mathrm{a}}$ & $395^{\mathrm{a}}$ & $3.30^{\mathrm{a}}$ & $1.72^{\mathrm{a}}$ \\
\hline \multicolumn{6}{|c|}{ Nitrogen $\left(\mathrm{kg} \mathrm{N} \mathrm{ha}^{-1}\right)$} \\
\hline Control & $909^{c}$ & $39.7^{\mathrm{a}}$ & $365^{\mathrm{b}}$ & $2.70^{\mathrm{b}}$ & $1.52^{\mathrm{c}}$ \\
\hline 30 & $948^{\mathrm{b}}$ & $38.6^{\mathrm{b}}$ & $371^{b}$ & $2.91^{\mathrm{b}}$ & $1.61^{\mathrm{b}}$ \\
\hline 60 & $1030^{\mathrm{a}}$ & $37.2^{\mathrm{c}}$ & $390^{\mathrm{a}}$ & $3.36^{\mathrm{a}}$ & $1.70^{\mathrm{a}}$ \\
\hline 90 & $1043^{\mathrm{a}}$ & $36.1^{\mathrm{d}}$ & $383^{\mathrm{ab}}$ & $3.60^{\mathrm{a}}$ & $1.75^{\mathrm{a}}$ \\
\hline \multicolumn{6}{|c|}{ Analysis of variance } \\
\hline Year $(\mathrm{Y})$ & $* *$ & $* *$ & $* *$ & ns & $* *$ \\
\hline Potassium (K) & $* *$ & $* *$ & $* *$ & $* *$ & $* *$ \\
\hline Nitrogen $(\mathrm{N})$ & $* *$ & $* *$ & $* *$ & $* *$ & $* *$ \\
\hline $\mathrm{K} \times \mathrm{N}$ & $* *$ & * & $* *$ & ns & ns \\
\hline $\mathrm{Y} \times \mathrm{N}$ & ns & $*$ & $*$ & ns & ns \\
\hline $\mathrm{Y} \times \mathrm{K}$ & ns & $* *$ & $*$ & ns & ns \\
\hline $\mathrm{Y} \times \mathrm{K} \times \mathrm{N}$ & $* *$ & ns & $*$ & ns & ns \\
\hline
\end{tabular}

$*$ and $* *$ indicate significance at $p<0.05$ and $p<0.01$, respectively; ns: not significant. $\dagger$ : means followed by the same letter(s) in each column are not significantly different at $p<0.05$.

TABLE 3: Effects of $\mathrm{N}$ doses and K application on seed yield, oil content, and oil yield of black cumin in 2011 and 2012.

\begin{tabular}{|c|c|c|c|c|c|c|c|}
\hline \multirow{2}{*}{ K application } & \multirow{2}{*}{ N level } & \multicolumn{2}{|c|}{ Seed yield $\left(\mathrm{kg} \mathrm{ha}^{-1}\right)$} & \multicolumn{2}{|c|}{ Oil content (\%) } & \multicolumn{2}{|c|}{ Oil yield $\left(\mathrm{kg} \mathrm{ha}^{-1}\right)$} \\
\hline & & 2011 & 2012 & 2011 & 2012 & 2011 & 2012 \\
\hline \multirow{5}{*}{ Control } & Control & 976 & 797 & 44.3 & 34.5 & 433 & 275 \\
\hline & 30 & 1053 & 851 & 42.6 & 32.6 & 448 & 277 \\
\hline & 60 & 1037 & 887 & 41.9 & 31.4 & 434 & 279 \\
\hline & 90 & 1115 & 885 & 40.8 & 30.3 & 455 & 269 \\
\hline & Mean & 1045 & 855 & 42.4 & 32.2 & 443 & 275 \\
\hline \multirow{5}{*}{$\mathrm{K}+$} & Control & 1001 & 863 & 45.5 & 34.6 & 455 & 299 \\
\hline & 30 & 1027 & 859 & 44.9 & 34.4 & 462 & 296 \\
\hline & 60 & 1245 & 950 & 43.1 & 32.6 & 536 & 310 \\
\hline & 90 & 1183 & 991 & 42.8 & 30.3 & 506 & 300 \\
\hline & Mean & 1114 & 916 & 44.1 & 33.0 & 490 & 301 \\
\hline $\mathrm{LSD}_{0.05}$ & & ns & 34.5 & ns & ns & ns & ns \\
\hline
\end{tabular}

ns: not significant.

(FAMEs) with $2 \mathrm{~N} \mathrm{KOH}$ in methanol at room temperature [30]. Analysis of FAMEs was carried out with a gas chromatograph (Agilent 6850, USA) equipped with an Agilent $5975 \mathrm{~N}$ mass selective detector and a capillary column: (30 m length, $0.25 \mathrm{~mm}$ ID, and $0.25 \mu \mathrm{m}$ film). The injector temperature was $250^{\circ} \mathrm{C}$. The oven temperature was held at $150^{\circ} \mathrm{C}$ (hold for $1 \mathrm{~min}$ ), ramped to $200^{\circ} \mathrm{C}$ at the rate of $2.0^{\circ} \mathrm{C} / \mathrm{min}$ (hold for $1 \mathrm{~min}$ ), and finally increased to $250^{\circ} \mathrm{C}$ at the rate of $25^{\circ} \mathrm{C} / \mathrm{min}$ (hold for $1 \mathrm{~min}$ ). The carrier gas was helium with a flow rate of $2 \mathrm{~mL} / \mathrm{min}$; the split rate was $1 / 50$. The fatty acids were identified by the comparison of retention times to known standards. The results were expressed as percentage ( $\mathrm{g}$ $100 \mathrm{~g}^{-1}$ ) of total fatty acid.
The experiment was established as two factors ( $\mathrm{N}$ and $\mathrm{K}$ applications) and as randomized complete block design combined over years with three replications. The data were subjected to analysis of variance (ANOVA) using SPSS for Windows (versions 20.0). The differences among the means were compared using the LSD values $(p<0.05$ and $p<0.01)$.

\section{Results and Discussion}

The main effects of year, $\mathrm{K}$, and $\mathrm{N}$ application on the investigated parameters were shown in Table 2, and the results obtained from each experimental year were given separately in Tables 3, 4, 5, and 6. A significant difference between the 
TABLE 4: Fatty acid composition of black cumin oil extracted from seeds under supplemental K in 2011 and 2012.

\begin{tabular}{|c|c|c|c|c|}
\hline \multirow{2}{*}{ Fatty acids } & \multicolumn{2}{|c|}{2011} & \multicolumn{2}{|c|}{2012} \\
\hline & Control & $\mathrm{K}+$ & Control & $\mathrm{K}+$ \\
\hline Myristic (14:0) & 0.180 & 0.183 & $0.180^{\mathrm{b}}$ & $0.205^{\mathrm{a} *}$ \\
\hline Palmitic $(16: 0)$ & $13.40^{\mathrm{b}}$ & $13.56^{\mathrm{a}}$ & $13.20^{\mathrm{b}}$ & $13.87^{\mathrm{a}}$ \\
\hline Palmitoleic $(16: 1)$ & 0.175 & 0.170 & 0.170 & 0.217 \\
\hline Stearic $(18: 0)$ & 3.515 & 3.630 & $2.807^{\mathrm{b}}$ & $3.180^{\mathrm{a}}$ \\
\hline Oleic $(18: 1)$ & $24.06^{\mathrm{b}}$ & $25.19^{\mathrm{a}}$ & $21.85^{\mathrm{b}}$ & $23.89^{\mathrm{a}}$ \\
\hline Linoleic $(18: 2)$ & $53.96^{\mathrm{a}}$ & $53.12^{\mathrm{b}}$ & $57.21^{\mathrm{a}}$ & $54.21^{\mathrm{b}}$ \\
\hline Linolenic (18:3) & 0.524 & 0.514 & 0.576 & 0.567 \\
\hline Arachidic (20:0) & 0.177 & 0.177 & 0.175 & 0.190 \\
\hline Eicosenoic $(20: 1)$ & 0.385 & 0.400 & 0.360 & 0.347 \\
\hline Eicosadienoic $(20: 2)$ & $2.425^{\mathrm{a}}$ & $2.290^{\mathrm{b}}$ & 2.720 & 2.843 \\
\hline Total & 98.80 & 99.23 & 99.25 & 99.52 \\
\hline SAFAs & 17.27 & 17.55 & 16.37 & 17.45 \\
\hline MUFAs & 24.62 & 25.76 & 22.38 & 24.45 \\
\hline PUFAs & 57.08 & 56.10 & 60.68 & 57.81 \\
\hline Total UFAs & 81.71 & 81.86 & 83.06 & 82.26 \\
\hline
\end{tabular}

* shows comparison between $\mathrm{K}$ applications in each year and means followed by the same line with different letters are significant at $p<0.05$. SAFA: saturated fatty acids; MUFA: monounsaturated fatty acids; PUFA: polyunsaturated fatty acids; UFA: unsaturated fatty acids; K+: $50 \mathrm{~kg} \mathrm{~K}^{-1}$.

TABLE 5: Effects of $\mathrm{N}$ doses and K application on stearic, palmitic, and oleic acid of black cumin in 2011 and 2012.

\begin{tabular}{|c|c|c|c|c|c|c|c|}
\hline \multirow{2}{*}{$\mathrm{K}$ application } & \multirow{2}{*}{ N level } & \multicolumn{2}{|c|}{ Stearic acid (\%) } & \multicolumn{2}{|c|}{ Palmitic acid (\%) } & \multicolumn{2}{|c|}{ Oleic acid (\%) } \\
\hline & & 2011 & 2012 & 2011 & 2012 & 2011 & 2012 \\
\hline \multirow{5}{*}{ Control } & Control & 3.52 & 2.81 & 13.4 & 13.2 & 24.1 & 21.7 \\
\hline & 30 & 3.54 & 2.89 & 13.9 & 13.2 & 24.5 & 22.0 \\
\hline & 60 & 3.55 & 2.84 & 14.2 & 13.1 & 25.4 & 22.6 \\
\hline & 90 & 3.55 & 2.99 & 13.6 & 13.2 & 25.9 & 22.5 \\
\hline & Mean & 3.54 & 2.88 & 13.8 & 13.2 & 25.0 & 22.1 \\
\hline \multirow{5}{*}{$\mathrm{K}+$} & Control & 3.30 & 2.91 & 13.5 & 13.9 & 25.2 & 23.9 \\
\hline & 30 & 3.69 & 3.09 & 13.6 & 13.9 & 25.7 & 24.0 \\
\hline & 60 & 3.71 & 2.67 & 13.5 & 14.0 & 26.0 & 24.0 \\
\hline & 90 & 3.51 & 2.36 & 13.7 & 13.8 & 25.9 & 24.1 \\
\hline & Mean & 3.55 & 2.76 & 13.6 & 13.9 & 25.7 & 24.0 \\
\hline $\mathrm{LSD}_{0.05}$ & & ns & ns & ns & $\mathrm{ns}$ & $\mathrm{ns}$ & ns \\
\hline
\end{tabular}

ns: not significant.

TABLE 6: Effects of N doses and K application on linoleic, linolenic, and eicosadienoic acid of black cumin in 2011 and 2012.

\begin{tabular}{|c|c|c|c|c|c|c|c|}
\hline \multirow{2}{*}{ K application } & \multirow{2}{*}{$\mathrm{N}$ level } & \multicolumn{2}{|c|}{ Linoleic acid (\%) } & \multicolumn{2}{|c|}{ Linolenic acid (\%) } & \multicolumn{2}{|c|}{ Eicosadienoic acid (\%) } \\
\hline & & 2011 & 2012 & 2011 & 2012 & 2011 & 2012 \\
\hline \multirow{5}{*}{ Control } & Control & 54.0 & 57.2 & 0.49 & 0.58 & 2.43 & 2.72 \\
\hline & 30 & 54.7 & 58.2 & 0.49 & 0.58 & 2.44 & 2.75 \\
\hline & 60 & 55.3 & 58.3 & 0.53 & 0.61 & 2.48 & 2.80 \\
\hline & 90 & 55.3 & 58.6 & 0.57 & 0.61 & 2.49 & 2.81 \\
\hline & Mean & 54.8 & 58.1 & 0.52 & 0.60 & 2.46 & 2.62 \\
\hline \multirow{5}{*}{$\mathrm{K}+$} & Control & 54.3 & 54.2 & 0.51 & 0.57 & 2.29 & 2.84 \\
\hline & 30 & 54.9 & 55.6 & 0.52 & 0.57 & 2.31 & 2.90 \\
\hline & 60 & 55.0 & 55.7 & 0.52 & 0.57 & 2.32 & 2.90 \\
\hline & 90 & 55.3 & 55.7 & 0.53 & 0.58 & 2.30 & 3.02 \\
\hline & Mean & 54.9 & 55.3 & 0.52 & 0.57 & 2.31 & 2.92 \\
\hline $\mathrm{LSD}_{0.05}$ & & ns & ns & ns & ns & ns & $\mathrm{ns}$ \\
\hline
\end{tabular}

ns: not significant. 


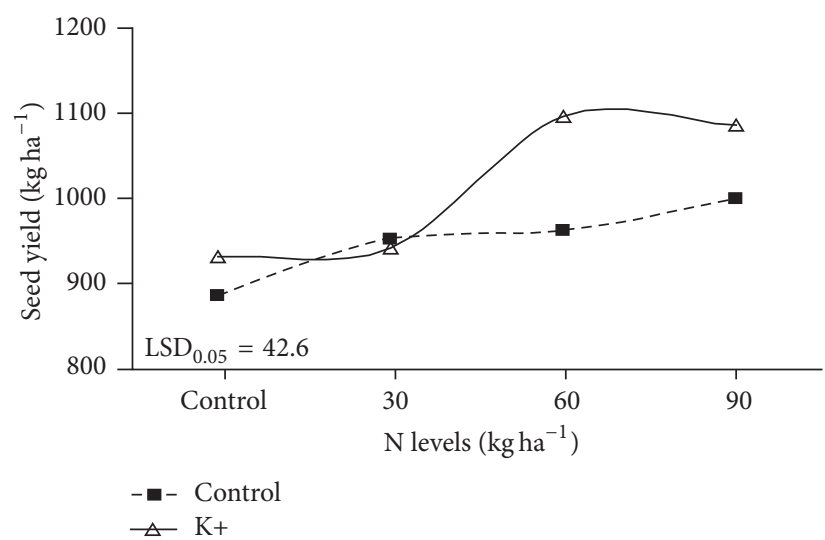

(a)

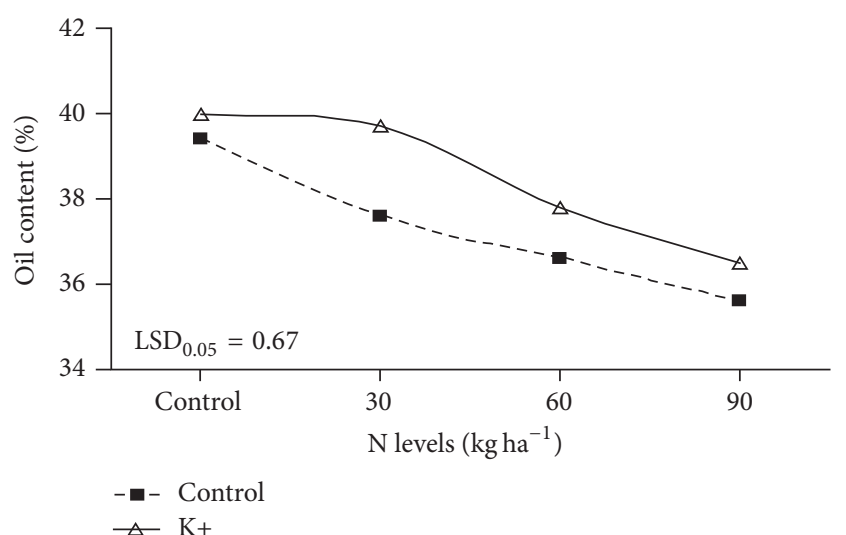

(b)

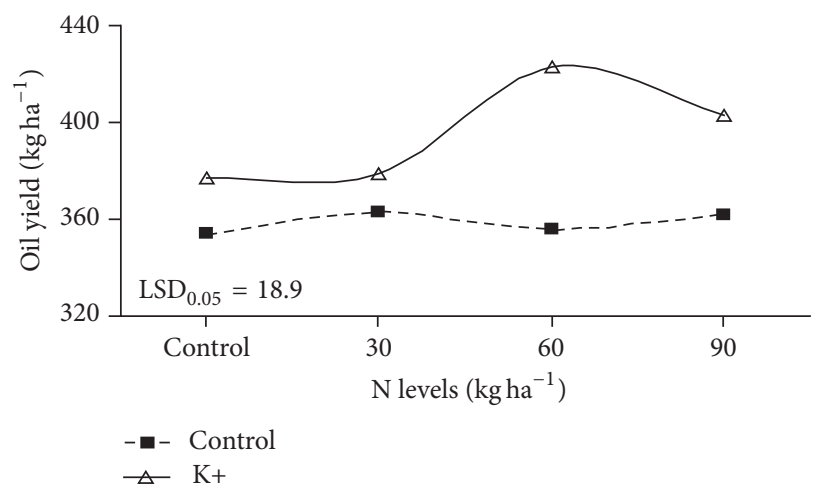

(c)

FIGURE 1: Changes in seed yield (a), oil content (b), and oil yield (c) of black cumin as affected by $\mathrm{N}$ doses and supplemental K application.

experimental years was determined in seed yield, oil content, and oil yield (Table 2). Mean seed yield, oil content, and oil yield were higher in the first year compared to the second year. This may be explained by higher precipitation and lower temperature in 2011 relative to 2012 . The average temperature was $14.8^{\circ} \mathrm{C}$ in 2011 and $15.3^{\circ} \mathrm{C}$ in 2012 . The total precipitation amount in the first experimental season (March-August) was higher $(223.9 \mathrm{~mm})$, and its distribution was more uniform than that in the second year $(168.4 \mathrm{~mm})$. Thus, higher seed yield, oil content, and oil yield were obtained in 2011.

The investigated characters except for fatty acid composition were significantly higher in the plants with supplemental $\mathrm{K}$ compared to the control (Table 2). The beneficial effects of K on seed yield of black cumin were detected. Likely, Sale and Campbell [31] found increases in soybean fruit yield and Rao et al. [32] in basil herb yield with increasing K supply. Also, increased $\mathrm{N}$ produced an increase in seed yield and oil yield, while it reduced oil content. The highest mean seed yield was obtained from $60 \mathrm{~kg} \mathrm{~N} \mathrm{ha}^{-1}$ but the oil content reached the minimum level in $90 \mathrm{~kg} \mathrm{Nha}^{-1}$. It was determined that there was no benefit for seed yield and oil content when $90 \mathrm{~kg} \mathrm{~N} \mathrm{ha}^{-1}$ was applied.

A significant two-way interaction between $\mathrm{N}$ and $\mathrm{K}$ applications was found for seed yield, seed oil content, and oil yield of black cumin (Table 3 ). The highest seed yield was obtained from the application of $50 \mathrm{~kg} \mathrm{Kha}^{-1}$ with $60 \mathrm{~kg} \mathrm{Nha}^{-1}$ as
$1245 \mathrm{~kg} \mathrm{ha}^{-1}$ in 2011, whereas seed yield was higher in $\mathrm{K}$ application with $90 \mathrm{~kg} \mathrm{Nha}^{-1}$ in 2012. Usually, the uptake of $\mathrm{K}$ by crops closely correlated with $\mathrm{N}$ uptake. Better $\mathrm{N}$ uptake and utilization with adequate $\mathrm{K}$ means improved the $\mathrm{N}$ use and resulted in higher yields. When adequate $\mathrm{K}$ is available, the addition of $\mathrm{N}$ and/or other nutrients increases $\mathrm{K}$ uptake, as the yields are increased [18]. Similarly, increasing doses of $\mathrm{N}$ and $\mathrm{K}$ resulted in improving seed yield of cottonseed [33], rosemary [34], rice, and barley [35]. Puttanna et al. [34] stated that $\mathrm{K}$ fertilization was necessary to obtain an optimum rosemary yield even if the soil was able to meet the crop requirements for $\mathrm{K}$. Our findings showed similar results: higher seed yields in the black cumin plants with supplemental $\mathrm{K}$ were observed even if the $\mathrm{K}$ content of the soil of the experiment was sufficient.

The oil content changed between 30.3 and $45.5 \%$ through the different $\mathrm{N}$ applications (Table 3). The oil content increased significantly with $\mathrm{K}$ application compared to the control but decreased with $\mathrm{N}$ doses in both years (Figure 1). The highest seed oil content was determined as 45.5\% in 2011 and $34.6 \%$ in 2012 by $50 \mathrm{~kg} \mathrm{Kha}^{-1}$ without $\mathrm{N}$ application. These results were in accordance with those of Ashraf et al. [15], who found that seed oil content was significantly higher at the control and at the lowest $\mathrm{N}$ dose $\left(30 \mathrm{~kg} \mathrm{~N} \mathrm{ha}^{-1}\right)$. Moreover, Özgüven and Sekeroğlu [16] and Shah [17] did not find any significant differences among $\mathrm{N}$ doses on the seed 
oil content of black cumin. Many studies on other oily seeds have shown that increasing the $\mathrm{N}$ dose resulted in reduction in seed oil content $[33,36-38]$. On the other hand, the oil content in seeds is usually low at suboptimal $\mathrm{K}$ supply, as found by Sale and Campbell [31] and Sawan et al. [33], because K plays a key role in fatty acid and lipid metabolism.

In the study, the oil yield ranged between 310 and $536 \mathrm{~kg} \mathrm{ha}^{-1}$ for the combination of $\mathrm{K}$ and $\mathrm{N}$ applications (Figure 1). The application of $\mathrm{N}$ and $\mathrm{K}$ significantly improved oil yield due to mainly enhancement in seed yield (Table 3 ). Higher oil yield was received from the plants with $\mathrm{K}$ application compared to the control; consequently, the maximum oil yield was detected in the interaction between $50 \mathrm{~kg} \mathrm{~K} \mathrm{ha}^{-1}$ and $60 \mathrm{~kg} \mathrm{Nha}^{-1}$.

The application of $\mathrm{N}$ and supplemental K caused a considerable increase in $\mathrm{N}$ and $\mathrm{K}$ content in seeds. Supplemental $\mathrm{K}$ improved both $\mathrm{N}$ and $\mathrm{K}$ content of seeds and each increase in $\mathrm{N}$ dose resulted in enhanced $\mathrm{N}$ content in seeds of black cumin. However, no significant difference between 60 and $90 \mathrm{~kg} \mathrm{Nha}^{-1}$ for $\mathrm{N}$ and $\mathrm{K}$ contents in seeds existed; they peaked at $90 \mathrm{~kg} \mathrm{Nha}^{-1}$.

The effect of $\mathrm{K}$ application on the fatty acid composition was significant $(p<0.05$, Table 4$)$. K application caused an increase in oleic and palmitic acid in both years and additionally stearic and myristic acids in 2012. Saturated fatty acids (SAFAs) such as palmitic, stearic, and myristic acids increased in small increments in both years with $\mathrm{K}$ application. For unsaturated fatty acids (UFAs), oleic acid (25.19 and 23.89\%) increased, while linoleic acid (53.12 and $54.21 \%$ ) declined in small increments with $\mathrm{K}$ application in either year (Table 5). Gaydou and Arrivets [39] found also an increase in oleic acid and a decrease in linoleic and linolenic acids in soybean by $\mathrm{K}$ application. They also determined a positive correlation between linoleic and linolenic acids and a negative correlation between linoleic and oleic acids. But Sawan et al. [33] reported that saturated fatty acids diminished, while unsaturated fatty acids enhanced with increasing $\mathrm{K}$ and $\mathrm{N}$ doses. Our findings revealed that $\mathrm{N}$ doses with or without $\mathrm{K}$ application had limited effects on fatty acid composition of black cumin as indicated by Ashraf et al. [15].

The oil of black cumin contains a high amount of linoleic acid (53.1 to 57.2\%) (Table 6). Linoleic acid, the main polyunsaturated fatty acid (PUFA), was found to be high in many studies [11, 40,41]. The results showed that UFAs (palmitoleic acid, oleic acid, linoleic acid, linolenic acid, eicosenoic acid, and eicosadienoic acid) account for between 81.71 and $83.06 \%$; the main monounsaturated fatty acid (MUFA) was oleic acid, and the main SAFA was palmitic acid. The total MUFAs, PUFAs, and SAFAs compositions were between 22.38 and $25.76 \%$, between 56.10 and $60.68 \%$, and between 16.36 and $17.55 \%$, respectively. The ratio of linoleic acid to oleic acid was almost $2: 1$. These results are in accordance with Cheikh-Rouhou et al. [11] and Al-Naqeeb et al. [40].

This study revealed that the highest seed yield and oil yield in black cumin were obtained from the applications of $60 \mathrm{~kg} \mathrm{Nha}^{-1}$ with supplemental $\mathrm{K}$ in both years, while oil content reduced by increasing $\mathrm{N}$ doses. The main components of oil were linoleic (54.5\%), oleic (23.5\%), and palmitic acids (13.5\%), which were not clearly influenced by fertilization. SAFAs, palmitic acid, stearic acid, and myristic acid, were slightly increased by $\mathrm{K}$ application. Oleic acid increased, whereas linoleic acid decreased with K application in either year, but these differences were too small to evaluate for practical purposes. In terms of reducing environmental risks such as leaching, contamination, and excessive nitrate accumulation in plant parts, application of $90 \mathrm{~kg} \mathrm{Nha}^{-1}$ should be avoided. It was concluded that $\mathrm{K}$ application should be advised for enhancement of seed yield, oil content, and oil yield of black cumin and the effective $\mathrm{N}$ dose was determined as $60 \mathrm{~kg} \mathrm{Nha}^{-1}$.

\section{Conflicts of Interest}

The authors declare that they have no conflicts of interest.

\section{Acknowledgments}

The authors would like to give their sincere thanks to Professor Dr. M. Demir KAYA for his valuable comments.

\section{References}

[1] I. B. Ipor and L. P. A. Oyen, "Nigella sativa L.," Plant Resources of South-East Asia, pp. 148-151, 1999.

[2] S. Raghavan, Handbook of Spices, Seasonings, and Flavorings, CRC Press, Fla, USA, 2nd edition, 2006.

[3] M. Burits and F. Bucar, "Antioxidant activity of Nigella sativa essential oil," Phytotherapy Research, vol. 14, no. 5, pp. 323-328, 2000.

[4] M. L. Mathur, J. Gaur, R. Sharma, and K. R. Haldiya, "Antidiabetic properties of a spice plant Nigella sativa," Journal of Endocrinology and Metabolism, vol. 1, no. 1, pp. 1-8, 2011.

[5] M. Kanter, O. Coskun, and H. Uysal, “The antioxidative and antihistaminic effect of Nigella sativa and its major constituent, thymoquinone on ethanol-induced gastric mucosal damage," Archives of Toxicology, vol. 80, no. 4, pp. 217-224, 2006.

[6] F. R. Dehkordi and A. F. Kamkhah, "Antihypertensive effect of Nigella sativa seed extract in patients with mild hypertension," Fundamental and Clinical Pharmacology, vol. 22, no. 4, pp. 447452, 2008.

[7] M. S. Al-Ghamdi, "The anti-inflammatory, analgesic and antipyretic activity of Nigella sativa," Journal of Ethnopharmacology, vol. 76, no. 1, pp. 45-48, 2001.

[8] M. S. M. Hanafy and M. E. Hatem, "Studies on the antimicrobial activity of Nigella sativa seed (black cumin)," Journal of Ethnopharmacology, vol. 34, no. 2-3, pp. 275-278, 1991.

[9] D. Musa, N. Dilsiz, H. Gumushan, G. Ulakoglu, and M. Bitiren, "Antitumor activity of an ethanol extract of Nigella sativa seeds," Biologia-Section Cellular and Molecular Biology, vol. 59, no. 6, pp. 735-740, 2004.

[10] E. S. Abdel-Aal and R. S. Attiai, "Characterization of black cumin (Nigella sativa) seeds 1-chemical composition and lipids," Alexandria Science Exchange, vol. 14, pp. 467-467, 1993.

[11] S. Cheikh-Rouhou, S. Besbes, B. Hentati, C. Blecker, C. Deroanne, and H. Attia, "Nigella sativa L.: chemical composition and physicochemical characteristics of lipid fraction," Food Chemistry, vol. 101, no. 2, pp. 673-681, 2007. 
[12] I. Hamrouni-Sellami, M. E. Kchouk, and B. Marzouk, "Lipid and aroma composition of black cumin (Nigella sativa L.) seeds from Tunisia," Journal of Food Biochemistry, vol. 32, no. 3, pp. 335-352, 2008.

[13] L. F. D'Antuono, A. Moretti, and A. F. S. Lovato, "Seed yield, yield components, oil content and essential oil content and composition of Nigella sativa L. and Nigella damascena L.," Industrial Crops and Products, vol. 15, no. 1, pp. 59-69, 2002.

[14] B. Mokhele, X. Zhan, G. Yang, and X. Zhang, "Review: Nitrogen assimilation in crop plants and its affecting factors," Canadian Journal of Plant Science, vol. 92, no. 3, pp. 399-405, 2012.

[15] M. Ashraf, Q. Ali, and Z. Iqbal, "Effect of nitrogen application rate on the content and composition of oil, essential oil and minerals in black cumin (Nigella sativa L.) seeds," Journal of the Science of Food and Agriculture, vol. 86, no. 6, pp. 871-876, 2006.

[16] M. Özgüven and N. Sekeroǧlu, "Agricultural practices for high yield and quality of black cumin (Nigella sativa L.) cultivated in Turkey," Acta Horticulturae, vol. 756, pp. 329-337, 2007.

[17] S. H. Shah, "Influence of nitrogen and phytohormone spray on seed, inorganic protein and oil yields and oil properties of Nigella stiva L.," Asian Journal of Plant Sciences, vol. 6, no. 2, pp. 364-368, 2007.

[18] M. Wang, Q. Zheng, Q. Shen, and S. Guo, "The critical role of potassium in plant stress response," International Journal of Molecular Sciences, vol. 14, no. 4, pp. 7370-7390, 2013.

[19] A. E. Johnston and G. F. J. Milford, "Potassium and nitrogen interactions in crops," Potash Development Association, 2012, http://www.pda.org.uk.

[20] D. Leikam, "Fertilizing for irrigated corn," in Guide to Best Management Practices, International Plant Nutrition Institute, Kansas State University, 2008.

[21] G. F. J. Milford and A. E. Johnston, "Potassium and nitrogen interactions in crop production," in Proceedings of the 615 International Fertilizer Society, pp. 4-14, NY, UK, 2007.

[22] M. S. Brar, S. K. Bijay-Singh, and C. H. Srinivasarao, "Role of potassium nutrition in nitrogen use efficiency in cereals," Research Findings, no. 29, 2011, http://www.ipipotash.org/en/ eifc/2011/29/5/english.

[23] J. Timsina, U. Singh, M. Badaruddin, C. Meisner, and M. R. Amin, "Cultivar, nitrogen, and water effects on productivity, and nitrogen-use efficiency and balance for rice-wheat sequences of Bangladesh," Field Crops Research, vol. 72, no. 2, pp. 143-161, 2001.

[24] A. Rutkowska, D. Pikuła, and W. Stępień, "Nitrogen use efficiency of maize and spring barley under potassium fertilization in long-term field experiment," Plant Soil and Environment, vol. 60, no. 12, pp. 550-554, 2014.

[25] A. J. Macdonald, D. S. Powlson, P. R. Poulton, and D. S. Jenkinson, "Unused fertiliser nitrogen in arable soils-its contribution to nitrate leaching," Journal of the Science of Food and Agriculture, vol. 46, no. 4, pp. 407-419, 1989.

[26] X.-T. Ju, G.-X. Xing, X.-P. Chen et al., "Reducing environmental risk by improving $\mathrm{N}$ management in intensive Chinese agricultural systems," Proceedings of the National Academy of Sciences of the United States of America, vol. 106, no. 9, pp. 3041-3046, 2009.

[27] T. K. Broschat, "Nitrate, phosphate, and potassium leaching from container-grown plants fertilized by several methods," HortScience, vol. 30, no. 1, pp. 74-77, 1995.

[28] M. A. Alfaro, S. C. Jarvis, and P. J. Gregory, "Factors affecting potassium leaching in different soils," Soil Use and Management, vol. 20, no. 2, pp. 182-189, 2004.
[29] AOCS, "Rapid determination of oil/fat utilizing high temperature solvent extraction," AOCS Official Procedure Am 5-04, 1999.

[30] IUPAC, Standard Methods for the Analysis of Oils. Fats and Derivatives. Standard Method 2, vol. 2, 507- International Union of Pure and Applied Chemistry, Oxford, UK, 1st supplement to 7th edition, 1992.

[31] P. W. G. Sale and L. C. Campbell, "Yield and composition of soybean seed as a function of potassium supply," Plant and Soil, vol. 96, no. 3, pp. 317-325, 1986.

[32] E. V. S. Rao, K. Puttanna, R. S. Ganesha Rao, and S. Ramesh, "Nitrogen and potassium nutrition of French basil (Ocimumbasilicum L.)," ournal of Spices and Aromatic Crops, vol. 16, no. 2, pp. 99-105, 2011.

[33] Z. M. Sawan, Hafezb, A. E. Basyony, and A. R. Alkassas, "Cottonseed, protein, oil yields and oil properties as affected by nitrogen fertilization and foliar application of potassium and a plant growth retardant," World Journal of Agricultural Sciences, vol. 2, no. 1, pp. 56-65, 2006.

[34] K. Puttanna, E. V. S. P. Rao, R. Singh, and S. Ramesh, "Influence of nitrogen and potassium fertilization on yield and quality of rosemary in relation to harvest number," Communications in Soil Science and Plant Analysis, vol. 41, no. 2, pp. 190-198, 2010.

[35] J. D. Beaton, "Response to potassium: yield and economics," in Potassium for Agriculture, Potash and Phosphate Institute, pp. 67-108, Atlanta, GA, USA, 1980.

[36] F. S and El-Nakhlawy., "Response of safflower to different levels of nitrogen, phosphorus, and potassium," Acta Agronomica Hungarica, vol. 40, no. 1-2, pp. 87-92, 1991.

[37] J. D. Scheiner, F. H. Gutiérrez-Boem, and R. S. Lavado, "Sunflower nitrogen requirement and $15 \mathrm{~N}$ fertilizer recovery in Western Pampas," Argentina European Journal of Agronomy, vol. 17, no. 1, pp. 73-79, 2002.

[38] R. F. Brennan and M. D. A. Bolland, "Influence of potassium and nitrogen fertiliser on yield, oil and protein concentration of canola (Brassica napus L.) grain harvested in south-western Australia," Australian Journal of Experimental Agriculture, vol. 47, no. 8, pp. 976-983, 2007.

[39] E. M. Gaydou and J. Arrivets, "Effects of phosphorus, potassium, dolomite, and nitrogen fertilization on the quality of soybean. Yields, proteins, and lipids," Journal of Agricultural and Food Chemistry, vol. 31, no. 4, pp. 765-769, 1983.

[40] G. Al-Naqeeb, M. Ismail, and A. S. Al-Zubairi, "Fatty acid profile, $\alpha$-tocopherol content and total antioxidant activity of oil extracted from Nigella sativa seeds," International Journal of Pharmacology, vol. 5, no. 4, pp. 244-250, 2009.

[41] S. Bourgou, I. Bettaieb, M. Saidani, and B. Marzouk, "Fatty acids, essential oil, and phenolics modifications of black cumin fruit under nacl stress conditions," Journal of Agricultural and Food Chemistry, vol. 58, no. 23, pp. 12399-12406, 2010. 

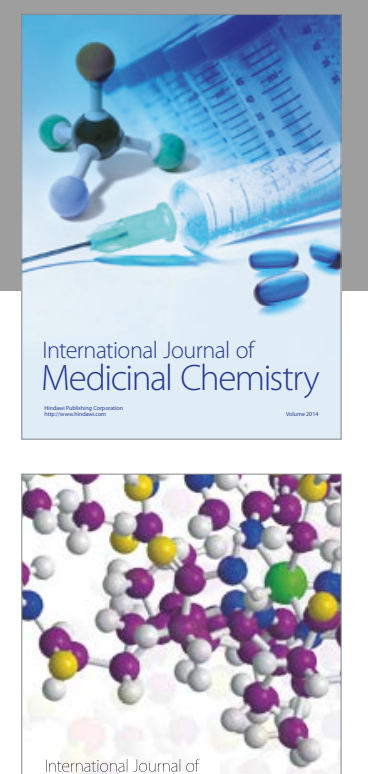

Carbohydrate Chemistry

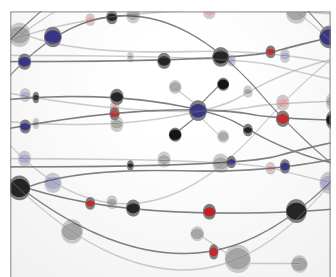

The Scientific World Journal
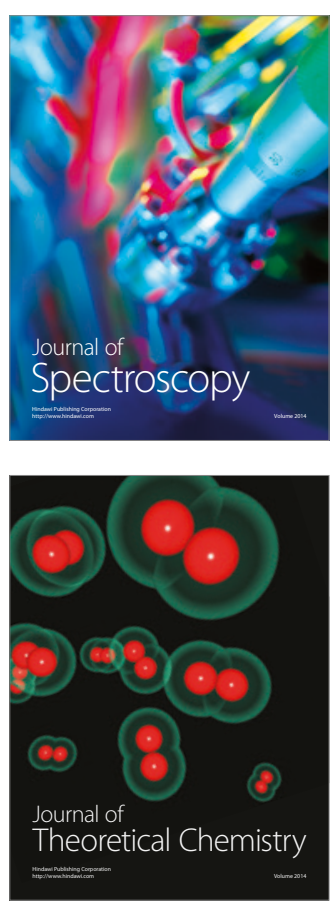
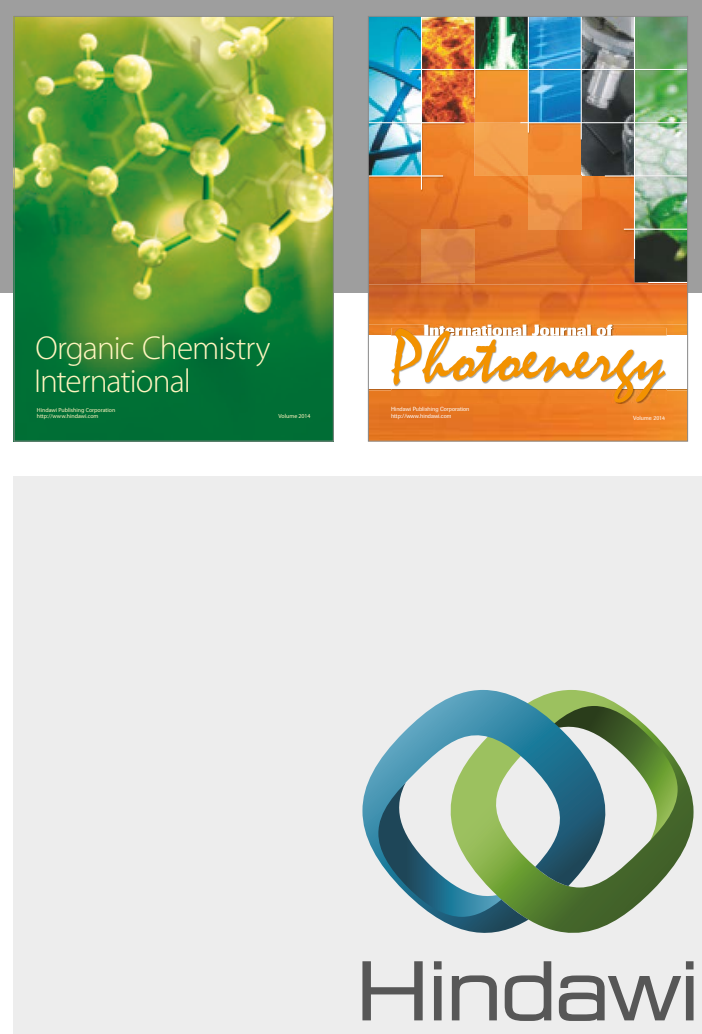

Submit your manuscripts at

https://www.hindawi.com

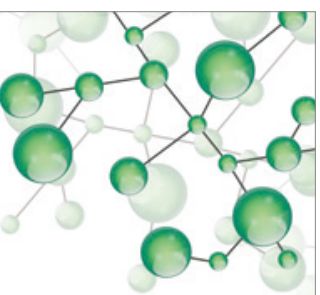

International Journal of

Inorganic Chemistry

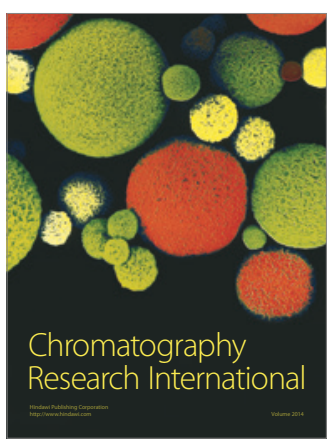

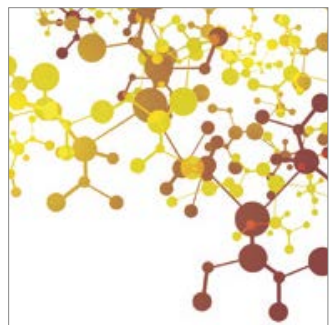

Applied Chemistry
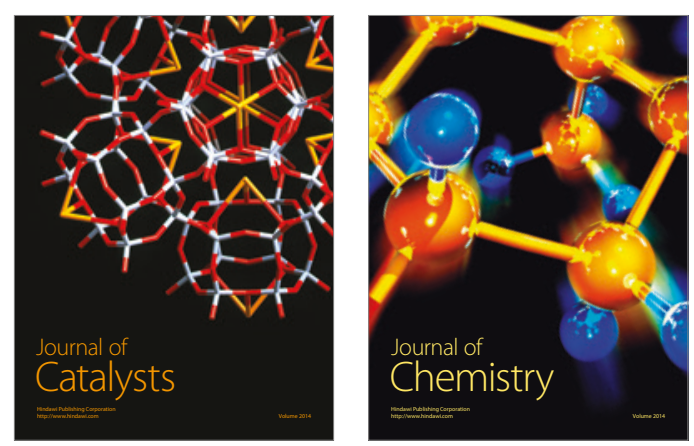
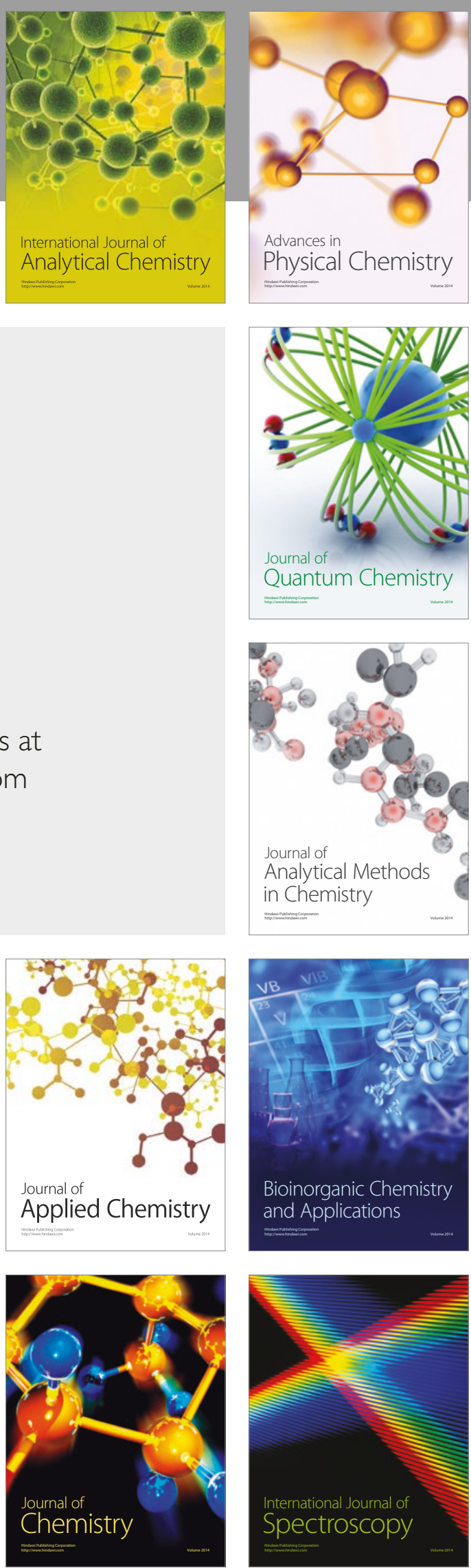